J. Product. \& Dev., 14(3): 583-595(2009)

\title{
RESPONSE OF Acokanthera spectabilis PLANTS TO SALINE WATER IRRIGATION
}

\author{
Amal Abdo Mohamed Nasr \\ Ornamental Horticulture Department, Faculty of Agriculture, Cairo \\ University, Cairo, Egypt
}

\begin{abstract}
A pot experiment was carried out during two successive seasons, 2007 and 2008 to study the tolerance of acokanthera plants to saline water irrigation. The data revealed that there were significant reductions in plant height, stem diameter, number of leaves with saline water treatments above $3000 \mathrm{ppm}$, the decreases were in proportion to the increase in salinity level. Also, the data indicated that in both seasons, there were no significant decreases in fresh weight of leaves and stems as the level of salinity increased to $3000 \mathrm{ppm}$. A marked increase, but not significant, in the fresh weight of roots, in both seasons, was obtained with the lowest level of salinity(1500 ppm).Irrigating the plants with saline water at 1500 or 3000 ppm insignificantly reduced leaf area, in both seasons. There were significant increase in dry weight of leaves when plants were irrigated with the lowest salinity levels (1500 and 3000 ppm) as compared with the control, irrigating the plants with stalinized water above 3000 ppm significantly decreased the dry weight of leaves, the dry weight of stems markedly increased with the level of salinity at $1500 \mathrm{ppm}$. All saline water treatments decreased the content of chlorophyll $-a$ and- $b$. Growing plants under salinity stress markedly decreased the content of total carbohydrates. All the saline water treatments caused a remarkable increase in the proline content over the control plants. In both seasons, the N, $P$ and $K$ contents of different plant parts decreased as salinity level increased, whereas $\mathrm{Na}, \mathrm{Ca}$, and $\mathrm{Cl}$ contents increased.

Generally, this plant can be irrigated with saline water at 3000 ppm without harmful effect.
\end{abstract}

Key words: Acokanthera spectabilis, saline, water irrigation.

\section{INTRODUCTION}

Acokanthera oblongifolia (A. spectabilis) plant is a shrub or small tree up to $3.5 \mathrm{~m}$ height, it occurs all over eastern and central Africa (Bailey,1962). This plant contains several cardiac glycosides of which acovenoside. Acokanthra are 
evergreen shrubs, belong to the family Apocynaceae, and has been widely cultivated for ornament. The leaves are smooth and leathery, in opposite pairs or whorls of three on the twigs; sweet-scented tubular white flowers appear in dense clusters, followed by hard-stoned fruit, the shape and size of olives. Corolla white or pink tinged; it is a great plant for a fence, or as a specimen plant. The response of ornamental plants to saline stress is very important for landscape ping and gardening purposes. Plant growth is limited with different environmental conditions, as salt stress, which is the most important agricultural problem in arid and semiarid climate conditions and can cause harm to plants by pulling moisture out of roots and reducing the uptake of water and nutrients (Allison,1964) pointed out that growth of the plants grown under salinity stress may be checked or totally inhibited due to osmotic effect on plant roots, toxic effects of accumulated ions, or the combination of them. Salinity can directly affect nutrient uptake (Alam, 1994) or affects plant physiology through changes of water and ionic status in the cells or ionic imbalance (Hasegawa et al ,2000),reduces uptake of other mineral nutrients, such as N, P, K, Ca and Mn (Tester and Davenport, 2003; Mazher et al., 2006 and Ashour, 2008). Several workers studied the effect of saline water irrigation on vegetative growth, pigments and mineral contents of ornamental plants, Habib (2002) on Bougainvillea, Aly (2004) on Senna occidentalis, and Ashour(2008) on Plumbago.

\section{MATERIALS AND METHODS}

A pot experiment was carried out, during the two successive seasons, 2007 and 2008, at the Nursery of Ornamental Hort. Department, Faculty of Agriculture, Cairo University, to study the relative salt tolerance of Acokanthera spectabilis (A .oblongifolia) plant.

Thus, uniform seedlings (15-18 cm, height with 7-8 leaves) were individually planted on March, $5^{\text {th }}$, in both seasons, in $30 \mathrm{~cm}$ diameter clay pots filled with a mixture of clay + sand $(2: 1 \mathrm{v} / \mathrm{v})$, After three weeks, the plants were treated by the different saline water treatments: Tap water(control), 1500, 3000, 4500, 6000, and $7500 \mathrm{ppm}$. The plants were irrigated every 5 days with artificial stalinized water containing $\mathrm{NaCl}$ and $\mathrm{Ca} \mathrm{Cl}_{2}$ at $(1: 1 \mathrm{w} / \mathrm{w})$. Each pot was irrigated with $1 \frac{1}{2}$ liters of saline water. The plants were held under natural condition for 7 months. The plants were fertilized with NPK (1:1:1) at $10 \mathrm{~g} /$ pot, 3 time during season.

The data recorded at the end of season were: Plant height $(\mathrm{cm})$, stem diameter $(\mathrm{cm})$,number of branches, fresh and dry weights of leaves, stems and roots $(\mathrm{g})$.The contents of chlorophyll-a, $\mathrm{b}$ and total carotenoids were determined (mg/g of leaf F.W.) according to Saric et al (1976). Amino acid "proline" was 
determined according to Bates et al (1973). The contents of N, P, K, Ca, Na and $\mathrm{Cl}(\% \mathrm{D} . \mathrm{W})$ in the leaves, stems and roots were determined. The wet digestion procedure was performed (Piper, 1947).Total nitrogen content was determined using Nissler method according to (A.O.A.C., 1960). P-content was determined according to Trough and Mayer (1939). The percentages of K, Ca and $\mathrm{Na}$ were determined by using Atomic Absorption/flame Spectrophotometer according to the method of (Jackson, 1958). Cl-percent was determined by titration with 0.02 $\mathrm{N}$ silver nitrate using potassium chromate as an in dicatior. (A. O. A. C., 1960).

The experimental design was a complete randomized design. The treatments were replicated three times, and each replicate contained 4 plants. The obtained data were statistically analyzed using LSD test (Steel and Torrie,1980).

\section{RESULTS AND DISCUSSION}

\section{1- Effect of saline water irrigation on vegetative growth a- Plant height :}

The effects of saline water irrigation on plant height are shown in Table 1. The data indicate that, irrigating the plants with saline water $>3000 \mathrm{ppm}$ significantly reduced plant height in the first season, whereas in the second one all treatments (except $1500 \mathrm{ppm}$ ) significantly reduced it. Raising the level of salinity significantly reduced the plant height and the decreases were in proportion to the increase in the salinity level and plants subjected to salinity stress at $7500 \mathrm{ppm}$ were the shortest, resulting $33.85 \mathrm{~cm}$ and $29.32 \mathrm{~cm}$, in the in the first and second seasons, respectively.

Everado (1975) stated that the reduction in plant height may be due to the reduction in cell division and the inhibition of both cell elongation and activity of meristmatic tissues, whereas St. Arnaud and Vincent (1990) attributed this effect to the insufficient uptake of water and nutrients as well as sodic toxicity due to salinity stress. Similar findings were reported by Mazher et al. (2006) on Sesnania aegyptiaca and Ashour (2008) on Plumbago.

\section{b-Stem thickness}

The response of stem thickness to saline water irrigation (Table 1) show that irrigating the plants with the lowest salinity level resulted in the thickest stems $(0.730$ and $0.984 \mathrm{~cm})$ in the first and second seasons, respectively, however the differences did not attain the level of significance as compared with the control plants. A clear reduction in stem diameter was recorded when plants were grown under the different salinity treatments above $1500 \mathrm{ppm}$, and the reduction was in proportion with the level of salinity, i.e. the highest level (7500) gave the thinnest 
Table 1. Effect of saline water irrigation on plant height, stem diameter, number of branches and leaves of Ackocanthera spectabilis during at 2007 and 2008 seasons

\begin{tabular}{ccccccccc}
\hline Saline water & \multicolumn{2}{c}{$\begin{array}{c}\text { Plant height } \\
\text { levels (ppm) }\end{array}$} & \multicolumn{2}{c}{$\begin{array}{c}\text { Stem diameter } \\
(\mathbf{c m})\end{array}$} & \multicolumn{2}{c}{$(\mathbf{c m})$} & \multicolumn{4}{c}{ Number of } \\
\cline { 2 - 9 } & $\mathbf{2 0 0 7}$ & $\mathbf{2 0 0 8}$ & $\mathbf{2 0 0 7}$ & $\mathbf{2 0 0 8}$ & $\mathbf{2 0 0 7}$ & $\mathbf{2 0 0 8}$ & $\mathbf{2 0 0 7}$ & $\mathbf{2 0 0 8}$ \\
\hline Control & 46.74 & 43.52 & 0.721 & 0.955 & 2.70 & 3.00 & 26.28 & 30.16 \\
$\mathbf{1 5 0 0}$ & 45.14 & 45.96 & 0.730 & 0.984 & 3.45 & 2.88 & 28.98 & 29.26 \\
$\mathbf{3 0 0 0}$ & 45.05 & 39.88 & 0.719 & 0.798 & 2.50 & 2.42 & 25.88 & 26.76 \\
$\mathbf{4 5 0 0}$ & 42.93 & 38.36 & 0.632 & 0.746 & 2.55 & 1.95 & 22.12 & 20.85 \\
$\mathbf{6 0 0 0}$ & 39.74 & 34.18 & 0.604 & 0.701 & 2.68 & 2.06 & 21.15 & 20.26 \\
$\mathbf{7 5 0 0}$ & 33.85 & 29.32 & 0.560 & 0.630 & 2.26 & 1.86 & 17.60 & 14.90 \\
\hline L.S.D 5\% & $\mathbf{3 . 2 4}$ & $\mathbf{3 . 8 7}$ & $\mathbf{0 . 0 4 5}$ & $\mathbf{0 . 0 6 4}$ & $\mathbf{0 . 5 5}$ & $\mathbf{0 . 6 3}$ & $\mathbf{3 . 4 5}$ & $\mathbf{3 . 8 8}$ \\
\hline
\end{tabular}

stems in both seasons. In this regard St Arnaud and Vincent (1990) explained the reduction in plant growth by the reduction in cell division, inhibition of both cell elongation and activity of meristmatic tissues or the insufficient uptake of water and nutrients.

\section{Number of branches}

In the first season, data in Table (1) indicate that plants grown under the lowest salinity level (1500 ppm) formed the highest number of branches (3.45), whereas the least number was formed on the plants irrigating with the highest salinity level, giving.2.26 branches/ plant. In the second season, all salinity treatments reduced branching as compared with the control plants, and the reduction was statistically significant when the plants were grown under salt stress at $4500-7500 \mathrm{ppm}$...These findings are in agreement with those reported by El-Leithy and El-Khateeb (1992) on Theivitia nereifolia, they reported that salinity caused a significant reduction in the formation of branches per plant.

\section{d-Number of leaves}

The effects of saline water irrigation on formation of leaves are shown in Table 1. The data indicate that, in the first season, growing plants under salinity stress of $1500 \mathrm{ppm}$ encouraged the formation of leaves giving 28.98 leaves/ plant, which was insignificantly higher than the control plants (26.28 leaves/ plant), the number of leaves reached the minimum value (17.60) when the plants were irrigated with the highest level of salinity (7500 ppm). Data of the second season, reveal that irrigating the plants of with saline water at the level of 1500 and $3000 \mathrm{ppm}$, had no significant effect on the formation of leaves, as they produced 29.26 and 26.76 leaves/ plant, against 30.16 leaves/ plant, for the control. The lowest number of leaves (14.90) was obtained with plants grown under the highest salinity 
stress (7500 ppm). In this regard. Mazher et al. (2006) on Sesbania aegyptiaca found that saline water above $3000-9000$ ppm reduced most the vegetative growth parameters.

\section{e-Fresh weight of leaves, stem and roots}

In both seasons ( Table 2 ), there were no significant decreases in fresh weight of leaves as the level of salinity increased to $3000 \mathrm{ppm}$, compared with the control, irrigating the plants with salinized water at $1500 \mathrm{ppm}$ gave the heaviest fresh weight of leaves $(18.73 \mathrm{~g})$ in the first season. Whereas, in the second one, the control plants produced the heaviest fresh weight of leaves (20.76 g) .In both seasons, the lowest values of fresh weight of leaves were obtained when plants were grown under the highest salinity stress $(7500 \mathrm{ppm})$. Concerning the effect of salinity on fresh weight of stem (Table, 2), the data show, in both seasons, that there were no significant decreases in fresh weight of stems with the level of salinity at 1500 or 3000 ppm., compared with the control. Irrigating the plants with saline water at 4500 to $7500 \mathrm{ppm}$ significantly reduced it. A marked increase, but not significant, in the fresh weight of roots, in both seasons, was obtained with the lowest level of salinity (1500 ppm), this treatment gave the heaviest fresh weight of roots (4.10 and $4.02 \mathrm{~g}$ ) in the first and second seasons , respectively, against 3.77 and $3.80 \mathrm{~g}$, for the control ,in both seasons, respectively. As the fresh weight of leaves and stems, the fresh weight of roots reached to the minimum values, when the plants were grown under the highest salinity stress.

Table 2. Effect of saline water irrigation on fresh weight of leaves, stems and roots (g) and leaf area $\left(\mathrm{cm}^{2}\right)$ of Ackocanthera spectabilis, at of 2007 and 2008 seasons

\begin{tabular}{ccccccccc}
\hline $\begin{array}{c}\text { Saline water } \\
\text { levels (ppm) }\end{array}$ & \multicolumn{6}{c}{ Fresh weight (g) of } & \multicolumn{2}{c}{$\begin{array}{c}\text { Leaf area } \\
\mathbf{c m}^{2}\end{array}$} \\
\cline { 2 - 8 } & \multicolumn{2}{c}{ Leaves } & \multicolumn{2}{c}{ Stems } & \multicolumn{2}{c}{ Roots } & \multicolumn{2}{c}{} \\
\cline { 2 - 8 } & $\mathbf{2 0 0 7}$ & $\mathbf{2 0 0 8}$ & $\mathbf{2 0 0 7}$ & $\mathbf{2 0 0 8}$ & $\mathbf{2 0 0 7}$ & $\mathbf{2 0 0 8}$ & $\mathbf{2 0 0 7}$ & $\mathbf{2 0 0 8}$ \\
\hline Control & 18.55 & 20.76 & 8.76 & 10.21 & 3.77 & 3.80 & 14.65 & 14.80 \\
$\mathbf{1 5 0 0}$ & 18.73 & 19.55 & 10.00 & 9.71 & 4.10 & 4.02 & 14.44 & 15.00 \\
$\mathbf{3 0 0 0}$ & 17.93 & 18.32 & 7.91 & 8.80 & 3.28 & 2.96 & 14.23 & 14.54 \\
$\mathbf{4 5 0 0}$ & 15.82 & 15.00 & 5.55 & 7.58 & 3.22 & 3.08 & 13.10 & 12.60 \\
$\mathbf{6 0 0 0}$ & 15.32 & 12.50 & 5.56 & 5.89 & 3.00 & 2.71 & 10.85 & 9.35 \\
$\mathbf{7 5 0 0}$ & 11.08 & 9.67 & 5.28 & 6.00 & 2.91 & 2.26 & 9.20 & 8.56 \\
\hline L.S.D 5\% & $\mathbf{2 . 1 5}$ & $\mathbf{3 . 3 5}$ & $\mathbf{1 . 9 8}$ & $\mathbf{2 . 2 4}$ & $\mathbf{0 . 5 7}$ & $\mathbf{0 . 4 8}$ & $\mathbf{0 . 6 6}$ & $\mathbf{0 . 4 8}$ \\
\hline
\end{tabular}

\section{Leaf area}

As for the effect of saline water irrigation on leaf area (Table 2), the data indicate that, irrigating the plants with saline water at 1500 or $3000 \mathrm{ppm}$ insignificantly reduced it, in both seasons, as compared with the control. In the 
first season, the largest leaves were obtained when plant were irrigated with tap water $\left(14.65 \mathrm{~cm}^{2}\right)$ whereas in the second one, the lowest salinity treatment $(1500$ ppm) gave the largest leaves .Raising the level of salinity above 3000 ppm significantly reduced the area of leaves and the decreases were in proportion to the increase in the salinity level. the smallest leaves were obtained when pants subjected to salinity stress at $7500 \mathrm{ppm}$, resulting 9.20 and $8.56 \mathrm{~cm}^{2}$, in the in the first and second seasons, respectively. In this respect, St. Arnaud and Vincent (1990) attributed this effect to the insufficient uptake of water and nutrients. Mergulhao.et al (2002) on Brachiaria humidicola plant stated that salinity at E.C. $8 \mathrm{dSm}-1$ caused reduction in leaf area

\section{g-Dry weight of leaves, stems and roots.}

In the first season (Table 3), there were significant increase in dry weight of leaves when plants were irrigated with the lowest salinity levels (1500 and $3000 \mathrm{ppm}$ ) as compared with the control, irrigating the plants with salinized water above $3000 \mathrm{ppm}$ significantly decreased the dry weight of leaves, giving the lowest dry weight of leaves $(3.40 \mathrm{~g})$ with the highest salinity level.. Whereas, in the second season, irrigating the plants with salinized water at $1500 \mathrm{ppm}$ insignificantly increased the dry weight of leaves, giving $5.51 \mathrm{~g}$, against $5.05 \mathrm{~g}$ for the control. The lowest dry weight of leaves $(2.87 \mathrm{~g})$ was obtained when plants were grown under the highest salinity stress. Concerning the effect of salinity on dry weight of stem (Table 3), the data show, in both seasons, that the dry weight of stems markedly increased with the level of salinity at $1500 \mathrm{ppm}$., compared with the control, and irrigating the plants with saline water above 3000 ppm, significantly reduced it. In the first season, irrigating the plants with saline water at 1500 or $3000 \mathrm{ppm}$ had no significant effect on dry weight of roots. In the second season, also the lowest level of salinity $(1500 \mathrm{ppm})$ showed the same trend. As the fresh weight of roots, the dry weight reached to the minimum values, when the plants were grown under the highest salinity stress. In this regard, Mergulhao et al (2002) on Brachiaria humidicola plant stated that salinity at E.C. $8 \mathrm{dSm}-1$ caused reduction dry matter of shoots and roots. Mazher et al (2006) on Sesnania aegyptiaca found that saline water above $3000-9000$ ppm reduced most the vegetative growth parameters.

\section{2- Effect of saline water irrigation on chemical composition: a- Pigment content}

The response of chlorophyll-a, b and carotenoids contents of acokanthera to the application of saline water irrigation are presented in Table 4. In both seasons, all saline water treatments (except low level of salinity in the second season) decreased the content of chlorophyll- $a$ and $b$, as compared with the 
Table 3. Effect of saline water irrigation on dry weight of leaves, stem and roots (g/plant) of Ackocanthera spectabilis, at 2007 and 2008 seasons

\begin{tabular}{ccccccc}
\hline \multirow{2}{*}{$\begin{array}{c}\text { Saline water } \\
\text { levels (ppm) }\end{array}$} & \multicolumn{6}{c}{ Dry weight of (g) } \\
\cline { 2 - 7 } & \multicolumn{2}{c}{ Leaves } & \multicolumn{3}{c}{ Stems } & \multicolumn{2}{c}{ Roots } \\
\cline { 2 - 7 } & $\mathbf{2 0 0 7}$ & $\mathbf{2 0 0 8}$ & $\mathbf{2 0 0 7}$ & $\mathbf{2 0 0 8}$ & $\mathbf{2 0 0 7}$ & $\mathbf{2 0 0 8}$ \\
\hline Control & 4.88 & 5.05 & 2.49 & 2.04 & 1.02 & 1.22 \\
$\mathbf{1 5 0 0}$ & 5.74 & 5.51 & 2.97 & 2.32 & 0.88 & 1.02 \\
$\mathbf{3 0 0 0}$ & 5.18 & 4.96 & 2.48 & 1.98 & 0.97 & 0.83 \\
$\mathbf{4 5 0 0}$ & 4.25 & 4.50 & 1.66 & 1.70 & 0.79 & 0.88 \\
$\mathbf{6 0 0 0}$ & 4.14 & 3.66 & 1.30 & 1.65 & 0.79 & 0.75 \\
$\mathbf{7 5 0 0}$ & 3.40 & 2.87 & 1.33 & 1.41 & 0.65 & 0.70 \\
\hline L.S.D 5\% & $\mathbf{0 . 4 5}$ & $\mathbf{0 . 6 2}$ & $\mathbf{0 . 5 3}$ & $\mathbf{0 . 3 2}$ & $\mathbf{0 . 1 7}$ & $\mathbf{0 . 2 4}$ \\
\hline
\end{tabular}

Table 4. Effect of saline water irrigation on pigment contents $(\mathrm{mg} / \mathrm{g}$ F.W. of leaves) of Ackocanthera spectabilis, at 2007 and 2008 seasons

\begin{tabular}{ccccccc}
\hline \multirow{2}{*}{$\begin{array}{c}\text { Saline water } \\
\text { Levels (ppm) }\end{array}$} & \multicolumn{2}{c}{ Ch-a } & \multicolumn{2}{c}{ Ch-b } & \multicolumn{2}{c}{ Carotene } \\
\cline { 2 - 7 } Control & $\mathbf{2 0 0 7}$ & $\mathbf{2 0 0 8}$ & $\mathbf{2 0 0 7}$ & $\mathbf{2 0 0 8}$ & $\mathbf{2 0 0 7}$ & $\mathbf{2 0 0 8}$ \\
\hline $\mathbf{1 5 0 0}$ & 1.63 & 1.82 & 1.48 & 1.53 & 1.68 & 1.34 \\
\hline $\mathbf{3 0 0 0}$ & 1.60 & 1.84 & 1.30 & 1.65 & 1.76 & 1.50 \\
\hline $\mathbf{4 5 0 0}$ & 1.43 & 1.80 & 1.29 & 1.68 & 1.64 & 1.34 \\
\hline $\mathbf{6 0 0 0}$ & 1.44 & 1.72 & 1.23 & 1.40 & 1.53 & 1.24 \\
\hline $\mathbf{7 5 0 0}$ & 1.17 & 1.26 & 0.94 & 0.96 & 1.26 & 1.10 \\
\hline & $\mathbf{0 . 9 5}$ & $\mathbf{0 . 8 6}$ & $\mathbf{0 . 9 0}$ & $\mathbf{0 . 8 7}$ & $\mathbf{1 . 0 3}$ & $\mathbf{0 . 9 8}$ \\
\hline
\end{tabular}

control plants and the decrement in the content of chlorophyll - $\mathrm{a}$ and $\mathrm{b}$ was more pronounced with the high salinity levels. In both seasons, plants contained the highest values of carotene when grown under the lowest salinity level giving 1.76 and $1.5 \mathrm{mg} / \mathrm{g}$ F.W. respectively. These results are in agreement with those obtained by Mazher et al (2006) on Sesnania aegyptiaca found that salinity above $3000 \mathrm{ppm}$ decreased the content of chlorophyll $-\mathrm{a} \& \mathrm{~b}$ and increased caroteniods

\section{Total carbohydrates}

As for the effect of saline water irrigation on the contents of total carbohydrates In the different plant parts, data in (Table 2), indicate that, in the first season, irrigating the plants with saline water at $1500 \mathrm{ppm}$ insignificantly increased it, as compared with the control. In the second season, all salinity treatments reduced the Total carbohydrates in leaves and stems. A slight increase in the Total carbohydrates in the roots was observed in the second season with 
the lowest salinity treatment $(1500 \mathrm{ppm})$, whereas the other treatments reduced it. Generally, raising the level of salinity reduced the Total carbohydrates contents in the different plant parts and the decreases were in proportion to the increase in the salinity level. Hussein and Hagag (2003) on Asclepias curassavica found that saline water above $4500 \mathrm{ppm}$ reduced the content of carbohydrates, and Mazher et al (2006) on Sesnania aegyptiaca found that saline water from 3000 - 7000 ppm decreased the content of carbohydrates.

\section{Amino acid " Proline " content:}

The response of the amino acid " Proline " of acokanthera leaves to saline water irrigation are presented in Table 5. The content of amino acid " proline " in leaves ranged between 0.34 and $1.2 \mathrm{mg} / \mathrm{g}$ F.W., in the first season and between 0.25 and $0.95 \mathrm{mg} / \mathrm{g}$ F.W. in the second one. The obtained data clearly indicated that most of the saline water treatments caused a remarkable increase in the proline content over the control. In both seasons, plants had the highest value of proline content when were grown under the highest salinity stress. Begum and Karmoker (1999) suggested that proline produced in leaf is transported to the roots to regulate the osmotic potantial in cells under salinity.These results are in agreement with those obtained by El-Khateeb and Salim (1994) on Chrysanthemum frutescens, they reported that increasing salinity level of irrigation water gradually increased the content of amino acid " proline also, Shehata, et al (1994) on Ficus retusa (nitida) found that increasing salinity level above $6000 \mathrm{ppm}$ showed a great accumulation of proline in the leaves Mergulhao et al (2002) on Brachiaria humidicola plant stated that salinity at E.C. $8 \mathrm{dSm}-1$ increased proline content. Ashour (2008) on Plumbago capensis plant reported that the praline content in fresh leaves was increased steadily with raising the salt concentration in irrigation water.

Table 5. Effect of saline water irrigation on total carbohydrates (\% D.W.) in leaves, stems and roots and amino acid proline (mg/g F.W. of leaves) of Ackocanthera spectabilis, during 2007 and 2008 seasons

\begin{tabular}{|c|c|c|c|c|c|c|c|c|}
\hline \multirow{3}{*}{$\begin{array}{l}\text { Saline water } \\
\text { Levels (ppm) }\end{array}$} & \multicolumn{6}{|c|}{ Total carbohydrates \% D.W. } & \multirow{2}{*}{\multicolumn{2}{|c|}{$\begin{array}{c}\text { Proline } \\
\text { mg/g F.W. } \\
\text { in leaves }\end{array}$}} \\
\hline & Leaves & Stems & Roots & Leaves & Stems & Roots & & \\
\hline & \multicolumn{3}{|c|}{2007} & \multicolumn{3}{|c|}{2008} & 2007 & 2008 \\
\hline Control & 32.01 & 26.44 & 22.22 & 29.10 & 27.65 & 22.00 & 0.34 & 0.25 \\
\hline 1500 & 32.67 & 27.06 & 25.78 & 24.33 & 24.10 & 23.89 & 0.34 & 0.41 \\
\hline 3000 & 29.15 & 23.41 & 23.32 & 24.54 & 19.95 & 25.65 & 0.60 & 0.45 \\
\hline 4500 & 27.56 & 20.55 & 21.11 & 24.22 & 21.02 & 24.10 & 0.78 & 0.58 \\
\hline 6000 & 25.76 & 19.85 & 21.25 & 23.50 & 19.67 & 18.95 & 0.84 & 0.69 \\
\hline 7500 & 25.25 & 20.03 & 17.99 & 20.19 & 18.75 & 19.02 & 1.20 & 0.95 \\
\hline
\end{tabular}




\section{Minerals content:}

The data in Table (6) showed the percentages of $\mathrm{N}, \mathrm{P}$ and $\mathrm{K}$ in leaves, stems and roots of acokanthera plants as affected by saline water irrigation. The obtained results indicated that in both seasons, the $\mathrm{N}$ content of leaves and stems of acokanthera decreased as salinity levels increased. $\mathrm{N}$ content of roots were higher, when plants were irrigated with the lowest salt concentration .In both seasons, the P content of leaves, stems and roots of acokanthera increased with when plants were irrigated with the lowest salt concentration and decreased as salinity level increased above this level. Data clearly indicated that, saline water

Table 6. Effect of saline water irrigation on the of $\mathrm{N}, \mathrm{P}$ and $\mathrm{K} \%$ (D.W.) in the different plant parts of Ackocanthera spectabilis, at 2007 and 2008 seasons.

\begin{tabular}{|c|c|c|c|c|c|c|}
\hline \multirow{3}{*}{$\begin{array}{l}\text { Saline water } \\
\text { levels (ppm) }\end{array}$} & \multicolumn{6}{|c|}{ N-. } \\
\hline & Leaves & Stems & Roots & Leaves & Stems & Roots \\
\hline & \multicolumn{3}{|c|}{2007} & \multicolumn{3}{|c|}{2008} \\
\hline Control & 1.57 & 1.43 & 1.20 & 1.72 & 1.85 & 1.54 \\
\hline 1500 & 1.50 & 1.52 & 1.32 & 1.57 & 1.55 & 1.63 \\
\hline 3000 & 1.38 & 1.41 & 1.29 & 1.60 & 1.39 & 1.54 \\
\hline 4500 & 1.27 & 1.32 & 1.26 & 1.36 & 1.23 & 1.43 \\
\hline 6000 & 1.19 & 1.30 & 1.21 & 1.27 & 1.16 & 1.28 \\
\hline \multirow[t]{2}{*}{7500} & 0.92 & 1.00 & 1.17 & 1.13 & 0.85 & 1.02 \\
\hline & \multicolumn{6}{|c|}{$\mathbf{P}$} \\
\hline Control & 0.31 & 0.23 & 0.15 & 0.24 & 0.19 & 0.11 \\
\hline 1500 & 0.34 & 0.25 & 0.19 & 0.26 & 0.20 & 0.14 \\
\hline 3000 & 0.20 & 0.22 & 0.17 & 0.22 & 0.16 & 0.11 \\
\hline 4500 & 0.16 & 0.18 & 0.14 & 0.19 & 0.13 & 0.09 \\
\hline 6000 & 0.17 & 0.20 & 0.17 & 0.14 & 0.11 & 0.10 \\
\hline \multirow[t]{2}{*}{7500} & 0.14 & 0.17 & 0.17 & 0.14 & 0.12 & 0.13 \\
\hline & \multicolumn{6}{|c|}{$\mathbf{K}$} \\
\hline Control & 2.25 & 2.14 & 1.61 & 2.16 & 1.82 & 1.56 \\
\hline 1500 & 2.31 & 2.24 & 2.14 & 2.05 & 2.23 & 1.89 \\
\hline 3000 & 2.02 & 2.11 & 2.20 & 1.83 & 1.92 & 1.82 \\
\hline 4500 & 1.85 & 1.98 & 2.11 & 1.92 & 1.74 & 1.65 \\
\hline 6000 & 1.81 & 1.77 & 1.72 & 1.67 & 1.61 & 1.51 \\
\hline 7500 & 1.62 & 1.52 & 1.65 & 1.60 & 1.45 & 1.42 \\
\hline
\end{tabular}

treatment at $1500 \mathrm{ppm}$ caused a remarkable increase in the $\mathrm{K}$ content of leaves, stems and roots over the control, in both seasons, the other salinity treatments reduced it. Generally, it can be concluded that irrigating acokanthera plants with saline water above 1500 ppm decreased the content of $\mathrm{N}$ and $\mathrm{P}$ and $\mathrm{K}$ in different parts of plant; the decreases were in proportion with the level of salinity. These findings are in agreement with those obtained by El-Khateeb et al (1994) on tuberose, El-Khateeb and Salim (1994) on Chrysanthemum frutescens. Also, 
Hussein and Hagag (2003) on Asclepias curassavica, stated that the contents of $\mathrm{N}, \mathrm{P}, \mathrm{K}$ decreased as the salinity level increased.

\section{$\mathrm{Ca}, \mathrm{Na}$ and $\mathrm{Cl}$ percentage}

In both seasons (Table 7) all saline water treatments increased the contents of $\mathrm{Ca}, \mathrm{Na}$, and $\mathrm{Cl}$ in the leaves, stems and roots, as compared with the control plants. The increment in the content $\mathrm{Ca}, \mathrm{Na}$, and $\mathrm{Cl}$ was more pronounced with the higher salinity levels. Comparing the values of $\mathrm{Na}, \mathrm{Ca}$ and $\mathrm{Cl}-$ percent of different parts, it can be mentioned that the contents of $\mathrm{Na}, \mathrm{Ca}$ and $\mathrm{Cl}$ in the leaves and stems were higher than that of roots. Generally, it can be concluded that irrigating acokanthera, plants with saline water at all levels (1500-7500 ppm) increased the content of $\mathrm{Na}, \mathrm{Ca}$ and $\mathrm{Cl}$ in leaves, stems and roots and the increases were in proportion with the level of salinity. Similar results were obtained by Hasegawa et al. (2000) stated that high level of $\mathrm{Na}^{+}$and $\mathrm{Cl}^{-}$in the soil solution may depress nutrient-ion activities and produce extreme ratios of $\mathrm{Na}^{+} / \mathrm{Ca}^{2+}$. Mazher et al. (2006) on Sesnania aegyptiaca found that saline water above $3000-7000$ ppm increased $\mathrm{Na}, \mathrm{Ca}$ and $\mathrm{Cl}$.

Table 7. Effect of saline water irrigation on the of $\mathrm{Ca}, \mathrm{Na}$ and $\mathrm{Cl}, \%$ (D.W.) in the different plant parts of Ackocanthera spectabilis , at 2007 and 2008 seasons

\begin{tabular}{|c|c|c|c|c|c|c|}
\hline \multirow{3}{*}{$\begin{array}{l}\text { Saline water } \\
\text { levels (ppm) }\end{array}$} & \multicolumn{6}{|c|}{$\mathrm{Ca}$} \\
\hline & Leaves & Stems & Roots & Leaves & Stems & Roots \\
\hline & \multicolumn{3}{|c|}{2007} & \multicolumn{3}{|c|}{2008} \\
\hline Control & 1.42 & 1.37 & 1.29 & 1.57 & 1.26 & 1.32 \\
\hline 1500 & 1.53 & 1.42 & 1.41 & 1.55 & 1.33 & 1.33 \\
\hline 3000 & 1.56 & 1.59 & 1.50 & 1.63 & 1.37 & 1.35 \\
\hline 4500 & 1.56 & 1.54 & 1.61 & 1.67 & 1.39 & 1.40 \\
\hline 6000 & 1.59 & 1.62 & 1.64 & 1.73 & 1.46 & 1.43 \\
\hline \multirow[t]{2}{*}{7500} & 1.62 & 1.66 & 1.63 & 1.75 & 1.54 & 1.48 \\
\hline & \multicolumn{6}{|c|}{$\mathrm{Na}$} \\
\hline Control & 0.52 & 0.61 & 0.43 & 0.81 & 0.65 & 0.39 \\
\hline 1500 & 0.64 & 0.65 & 0.57 & 0.80 & 0.77 & 0.44 \\
\hline 3000 & 0.70 & 0.68 & 0.62 & 0.79 & 0.78 & 0.46 \\
\hline 4500 & 0.78 & 0.74 & 0.66 & 0.83 & 0.77 & 0.57 \\
\hline 6000 & 0.84 & 0.87 & 0.75 & 0.88 & 0.73 & 0.61 \\
\hline \multirow[t]{2}{*}{7500} & 0.87 & 0.90 & 0.80 & 0.92 & 0.78 & 0.62 \\
\hline & \multicolumn{6}{|c|}{$\mathrm{Cl}$} \\
\hline Control & 0.60 & 0.64 & 0.58 & 0.55 & 0.72 & 0.52 \\
\hline 1500 & 0.62 & 0.67 & 0.61 & 0.63 & 0.73 & 0.54 \\
\hline 3000 & 0.68 & 0.77 & 0.70 & 0.70 & 0.75 & 0.55 \\
\hline 4500 & 0.69 & 0.79 & 0.79 & 0.76 & 0.81 & 0.62 \\
\hline 6000 & 0.74 & 0.83 & 0.83 & 0.79 & 0.86 & 0.66 \\
\hline 7500 & 0.75 & 0.95 & 0.87 & 0.84 & 0.92 & 0.66 \\
\hline
\end{tabular}


Conclusively, Acokanthera plants can be irrigated with saline water at 3000 ppm without harmful effect.

\section{REFERENCES}

Alam, S.M. (1994). Nutrient by plants under stress conditions. Handbook of Plant and Crop Stress. Marcel Dekker, New York,.227-246.

Aly, S.S.(2004): Effect of irrigation intervals and salt concentrations on the growth and chemical composition of Senna occidentalis. M.Sc. Thesis Faculty of Agriculture, Cairo University, Cairo, Egypt.

Allison, L. E. (1964): Salinity relation to irrigation. Advan. Agronomy, 16:139-180.

A. O. A. C. (1960): Association of official Agricultural chemists. Official Methods of Analysis. 9 th $\mathrm{ed}$, Benjanin Franklin, Washington P.C., 832

Ashour, H. A (2008): A study of some factors affecting growth, flowering and chemical composition of Plumbago capensis THUN PLANTS. M. Sc. Thesis, Faculty of Agriculture, Cairo University, Cairo, Egypt.

Bailey, L.H. (1960): The Standard Encyclopedia of Horticulture. Mac Mill Lct. Co.

Bates, L. S.; Waldern, R. P. and Tears, L.D.(1973): Rapid determination of free proline under water stress studies. Plant and Soil, 39(1):205-207.

Begum, F. and Karmoker, J. L. (1999): Effect of salinity stress on the accumulation and distribution of proline. Rachis, 18 (1): 22-25. Soil and Fert. Abst. (2000): 63 (4):3776.

El-Khateeb, M. A.; El-Liethy, A. S. and El-Shatat, N. S. (1994): The response of Tuberose (Polianthes tuberosa) plants to saline water irrigation. Egyptian Journal of Applied Science, 9 (8): 192-211.

El-Khateeb, M.A. and Salim, M.A. (1994): The response of Chrysanthemum frutescens L. plants to saline water irrigation. Egyptian Journal of Applied Science, 9 (1): 30-43.

El-Liethy, A. S. and El-Khateeb, M. A. (1992): The response of Theveitia nereifolia plants to saline water irrigation. Bull. Faculty of Agriculture, Cairo University, Egypt, 43(1):313-332.

Everado, A.N., Stoxzy, H.L. and Mehuza, R.G. (1975): Effect of soil osmotic potential produced with two salts on plant water potential. Plant and Soil, 42(9): 619-627. 
Habib, A.M.E. (2002): Response of three cultivars of Bougainvillea Ms. Butte plants to saline water irrigation. Journal of Agriculture Science, Mansoura University, 27 (2):102 .

Hasegawa, P., Bressan, J. and Bohnert, H. (2000): Plant cellular and molecular responses to high salinity, Annual Rev. Plant Mol. Biol., 51: 463-499.

Hussein, M.M and Hagag, A.A (2003): Effect of irrigation intervals and salt concentration on the growth and chemical composition of Asclepias curassavica L. Annals Agricultre Science, Cairo, 48(1): 307-317.

Jackson, L. (1958): Soil Chemical Analysis. New Jersey Prentice, Hall, Inc.

Mazher, A.A, Rawya, A.E. A and El-Aziz, N.G. (2006): Effect of micribene under salt stress on nodulation, growth and chemical constituents of Sesbania aegyptiaca in sandy soil. Bull. National Research Centre, Cairo, 31(3):245-265.

Mergulhao, A.C. Burity, E.S. and Tabosa, H.A (2002). Salt stress response and praline accumulation in Brachiaria humidicola plants with or without mycrrihizal inoculation. Revista Argentina de Microbiology, 34 (2):77-83.

Piper, C. (1947): Soil and Plant Analysis. The University of Adeaida : 252-275.

Saric, M. ; Kastrori, R.; Curic, R.; Cupina, T. and Geric, I. (1976): Chlorophyll determination. Univ. Unoven sadu Parkikum is fizicalagize Bilzaka, Beogard, Hauncna, Anjiga, 215.

Shehata, M.S; A. El-Tantawy and H. A. Mansour (1994): Effect of saline irrigation water and growing media on growth and some chemical composition of Ficus retusa(nitida) seedlings. Journal of Agriculture Science, Mansoura University, 19(8), 2617-2635.

St. Arnaud, F. and Vincent, T.R. (1990): Effect of high salt levels on germination and growth of five ootentaullty utilizable plants. Journal of Environ. Hort ., 6(4) $118-121$.

Steel, R. G. and Torrie, S. H. (1980): Principles and Procedures of Statistics. Second Edition, Mc Grow-Hall Inc.

Tester, M. and R. Davenport (2003): $\mathrm{Na}^{+}$Tolerance and $\mathrm{Na}^{+}$Transport in Higher Plants. Annals of Botany, 91: 503-527.

Trough, E. and Mayer, A. (1939): Improvement in deiness colorimetric method for phosphorus and arsenic Ind. Eng. Chem. Annal. F. Journal, 1: 136-139. 


\section{استجابة نبات الاكوكانثر اللري بالماء الملحي}

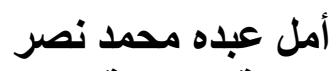 \\ قسم بساتين الزينة - كلية الزراعة - جامعة القاهرة -ج.ج.ع}

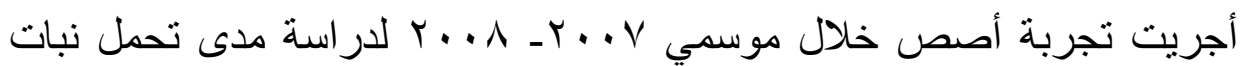

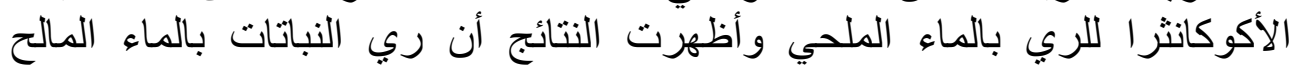

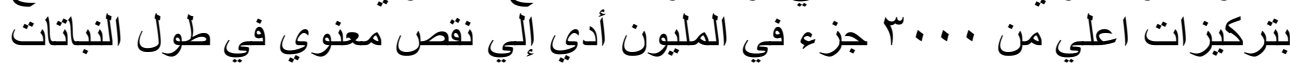

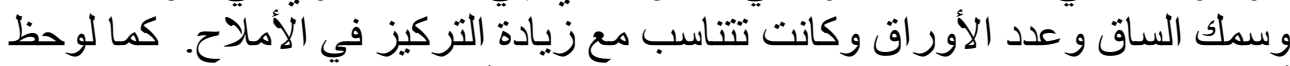

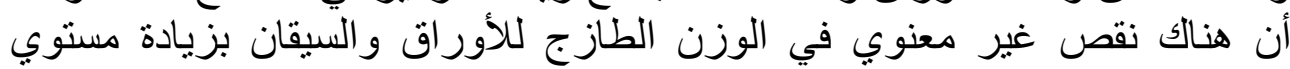

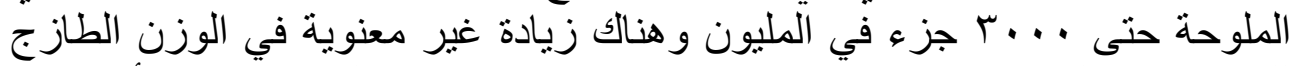

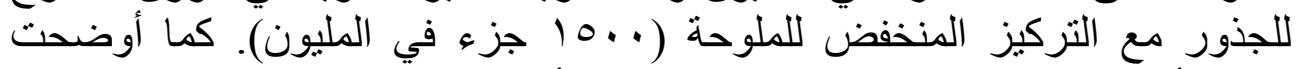

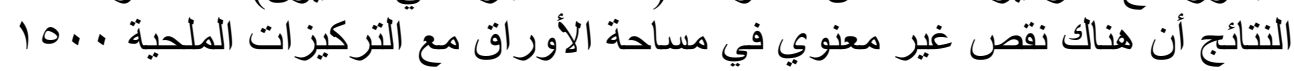

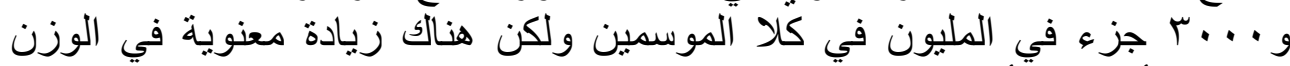

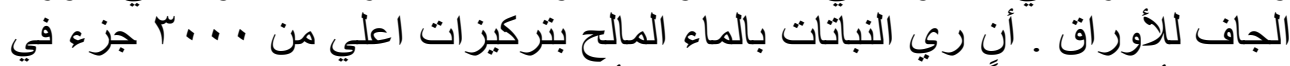

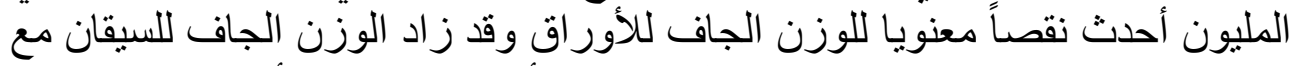

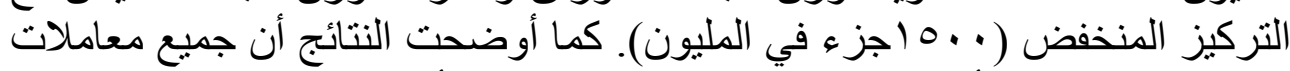

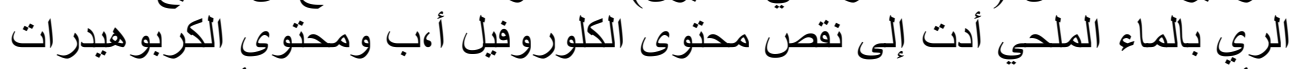

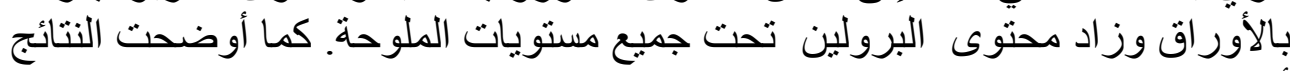

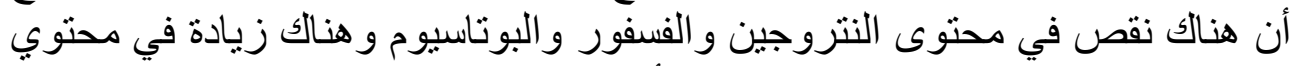

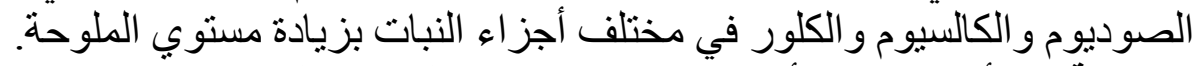

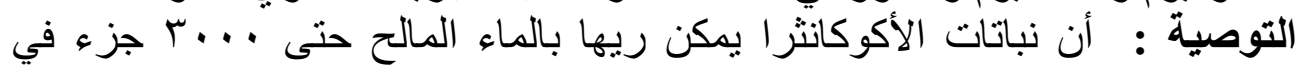

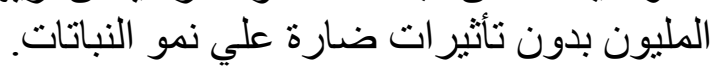

